\title{
Covariance function of Legendre polynomials for the modeling of Polled Nellore cattle growth in northern Brazil ${ }^{1}$
}

\author{
Funções de covariâncias sob polinômios de Legendre para \\ modelagem do crescimento de bovinos da raça Nelore Mocho da \\ região Norte do Brasil
}

\author{
Diego Helcias Cavalcante ${ }^{2 *}$; Severino Cavalcante Sousa Júnior ${ }^{3}$; Luciano Pinheiro \\ da Silva'; Carlos Henrique Mendes Malhado ${ }^{5}$; Raimundo Martins Filho ${ }^{6}$; \\ José Elivalto Guimarães Campelo ${ }^{7}$; Karina Rodrigues dos Santos ${ }^{3}$
}

\begin{abstract}
This study aimed to compare random regression models fitted by Legendre orthogonal polynomials and determine which best fits changes in Nellore cattle growth parameters. Age polynomial functions of different orders were evaluated using a random-effect modeling associated with a genetic study of cattle growth curves. For this purpose, weight records $(15,148)$ were performed in Polled Nellore bovines $(3,115)$, aged between 1 and 660 days, reared in northern Brazil and born between 1995 and 2010. The fixed effects of analytical models comprised age-matched groups, heifer calving age (linear and quadratic), and fourth-order Legendre age polynomial (cubic), depicting the mean growth curve. Besides, different order functions were considered for random effects, so that (co) variance associated with genetic effects (direct and maternal) and permanent environmental effects (animal and maternal) could be modeled. Residual variance was fitted by six heterogeneous classes throughout the analyzed period. According to AIC and BIC criteria, the model 6333 allowed the fitting of changes in variance and covariance over time (genetic and environmental). Thus, this model can be used to describe agerelated changes in Polled Nellore cattle reared in northern Brazil.
\end{abstract}

Key words: Genetic parameters. Growth track. Linear models. Random regression models.

\section{Resumo}

Objetivou-se comparar diferentes modelos de regressão aleatória ajustados por polinômios ortogonais de Legendre com a finalidade de determinar o mais adequado para descrever mudanças nos parâmetros de avaliação do crescimento de bovinos Nelore. Funções polinomiais da idade de diferentes ordens foram avaliadas na modelagem dos efeitos aleatórios associados ao estudo genético da curva de crescimento de bovinos. Utilizaram-se 15148 registros de pesos de 3115 de bovinos Nelore Mocho,

1 Parte da Tese de Doutorado do primeiro autor.

2 Prof. Dr., Universidade Federal do Piauí, UFPI, Bom Jesus, PI, Brasil. E-mail: diegohelcias@hotmail.com

3 Profs. Drs., Universidade Federal do Piauí, UFPI, Parnaíba, PI, Brasil. E-mail: sevzoo@yahoo.com.br; krsantos2004@yahoo. com.br

4 Prof. Dr., Universidade Federal do Ceará, UFC, Fortaleza, CE, Brasil. E-mail: lucianozooufv@yahoo.com.br

5 Prof. Dr., Departamento de Ciências Biológicas, Universidade Estadual do Sudoeste da Bahia, UESB, Jequié, BA, Brasil. E-mail: carlosmalhado@gmail.com

6 Prof. Visitante, Universidade Federal do Cariri, UFCA, Juazeiro do Norte, CE, Brasil. E-mail: rmartinsfilho@yahoo.com.br

7 Prof. Dr., Universidade Federal do Piauí, UFPI, Teresina, PI, Brasil. E-mail: jelivalto@hotmail.com

* Author for correspondence 
com idade entre 1 e 660 dias, criados na região norte do Brasil e nascidos entre os anos de 1995 e 2010. Os efeitos fixos incluídos nos modelos de análise foram: grupos de contemporâneos, a idade da vaca ao parto (efeito linear e quadrático) e os polinômios de Legendre da idade de quarta ordem (cúbica) para representar a curva média de crescimento. Na parte aleatória, consideraram-se funções de diferentes ordens para modelar as variâncias associadas aos efeitos genéticos aditivos direto e materno e aos efeitos de ambiente permanente do animal e da mãe. A variância residual foi ajustada por meio de seis classes heterogêneas, distribuídas ao longo do período analisado. De acordo com o valor do critério AIC e BIC o modelo com ordens 6333 (para efeitos genético direto e materno; e ambiente permanente direto e materno, respectivamente), permitiu ajustar as mudanças das variâncias e covariâncias com o tempo, podendo ser utilizado para descrever as mudanças nas variâncias com a idade dos bovinos Nelore Mocho criados na região Norte do Brasil.

Palavras-chave: Modelos de regressão aleatória. Modelos lineares. Parâmetros genéticos. Trajetória de crescimento.

\section{Introduction}

Genetic breeding is a tool used to increase Brazilian meat production, mainly beef - the most produced and exported by the country. Among the methods available for the genetic evaluation of production animals, random regression models for growth parameters are efficient since they use animal weight records without age-based adjustments (MALHADO et al., 2008). Random regression models are fitted using covariance matrices; hence, covariance functions become efficient alternatives to estimate such components (SOUSA JÚNIOR et al., 2010).

When adjusting random regression models, continuous functions are inherently fitted, which allows describing both genetic and environmental changes over time. In several studies, Legendre orthogonal polynomials have been used as continuous functions (KIRKPATRICK; HECKMAN, 1989; MEYER; HILL, 1997; JAMROZIK; SCHAEFFER, 1997; MEYER, 2007; BOLIGON et al., 2010), which may require a distinct fitting-order for each random effect of the model.

Beef cattle genetic programs have included growth parameters in evaluations, selecting the best animals in accordance with their predicted genetic values; therefore, cattle raising success depends on the accuracy of the breeding values predicted by these growth models.
In this context, suitable models are needed to obtain reliable estimates of genetic parameters, with the aim of classifying the best animals in terms of genetic potential. Thus, the average production of a population could be increased (BOLIGON et al., 2010; GONÇALVES et al., 2011; LAUREANO et al., 2011).

Currently, the Brazilian cattle herd is $90 \%$ Nellore. Given the above background, this study aimed to select the best random regression model to describe changes in growth parameters of Polled Nellore cattle, reared in the north of the country.

\section{Material and Methods}

\section{Data description}

Data were gathered from livestock participating in the Weight Development Program of the Brazilian Zebu Breeders Association (ABCZ, 2012). The herds are located in seven states of the north region of Brazil (Amazonas, Acre, Amapá, Amazonas, Rondônia, Pará, and Tocantins).

At first, the database had 44,106 weight records; then, this information was edited out, eliminating records of animals with more 660 days of age, animals without father's and/or mother's identifications, animals with less than 3 weight records, and age-matched groups with less than 3 animals. 
Within the age-matched groups, animals were grouped by sex, birth year, calving season, weight measure, weighing month, farm and breeding conditions. The calving seasons were classified into rainy (December to May) and dry (June to November); while the breeding conditions were divided into milk-fed and weaned animals (fed pasture).

To delete records with measurement errors (outliers), data consistency was analyzed through observations of significant variabilities within each age-matched group. Weight records out of the range given by the mean of the age-matched group $( \pm 3$ standard deviations) were excluded. As a result, a total of 1,819 age-matched groups with an average of 8.3 records were observed.

After editing, the database had 15,148 weight records belonging to 3,115 animals, born between 1995 and 2010 and fed pasture, with a mean birth weight of $28 \mathrm{~kg}$. Figure 1 shows mean weight and number of records by age.

Figure 1. Registration number and mean body weight per age of Polled Nellore cattle in northern Brazil.

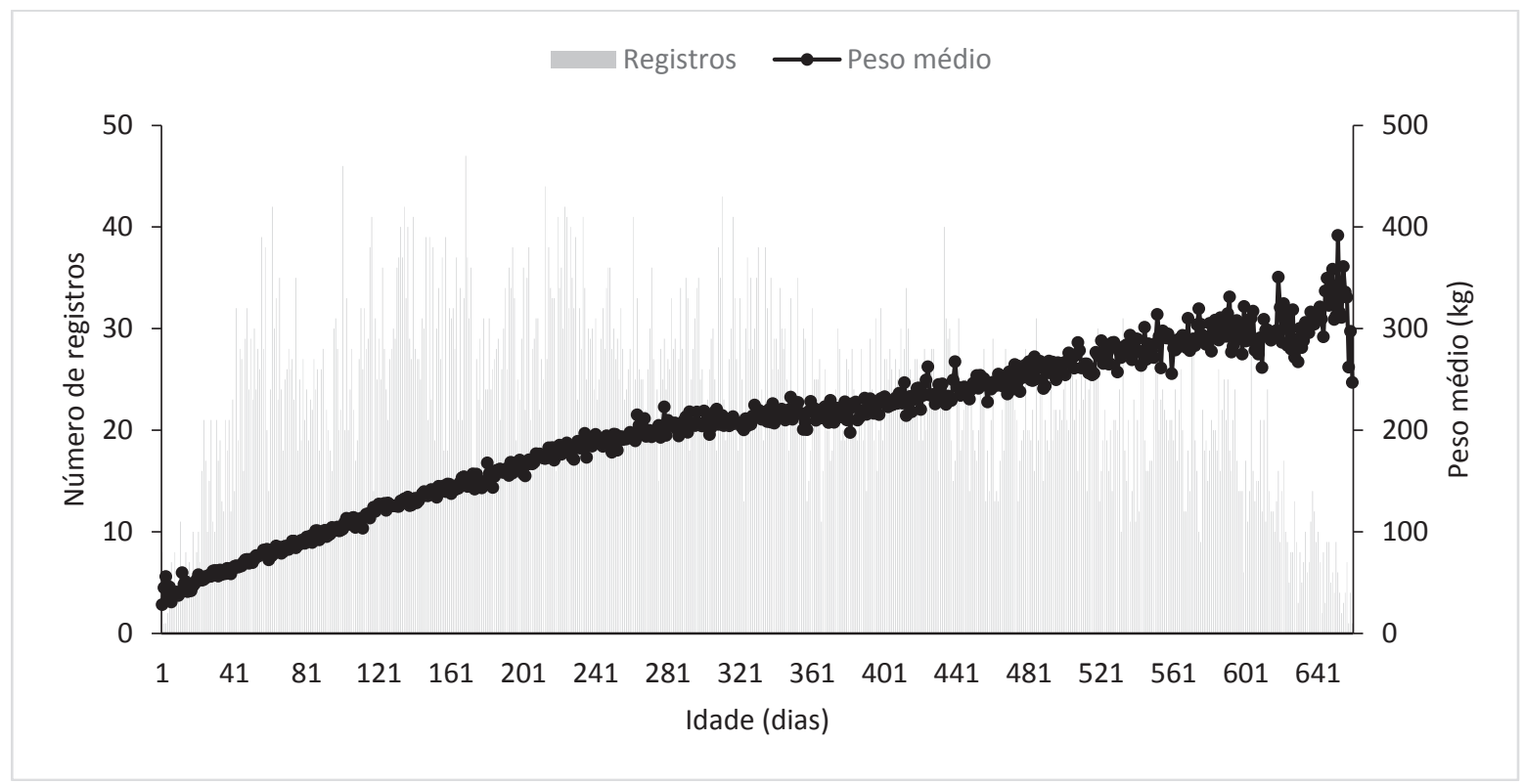

Animal weight records were grouped into 117 age classes. Each class consisted of a 5-day-of-age interval, except for those at the beginning and end of the curve, in which it was 15 days of age. This is because the frequency of records within these ranges decreased, as observed in Figure 1.
Table 1 shows data structure, number of observations per animal, and pedigree information. Editing and consistency analyses were performed using SAS software version 9.0. 
Table 1. Summary of the data structure from Polled Nellore cattle reared in northern Brazil.

\begin{tabular}{lc}
\hline Information & Quantity \\
\hline Data & 15,148 \\
Animals with observation & 3,115 \\
With 3 observations & 712 \\
With 4 observations & 698 \\
With 5 observations & 549 \\
With 6 observations & 659 \\
With 7 to 10 observations & 497 \\
Reproducers & 282 \\
Matrices & 764 \\
Animals in the matrix of kinship & 5,678 \\
Contemporary Groups & 1,819 \\
\hline
\end{tabular}

\section{Models and analyses}

For the random regression models, the agematched group was considered as a fixed effect, having as covariates the age at weighing and heifer age at calving (linear and quadratic effects). Yet, additive genetic direct and maternal effects, as well as animal and maternal permanent environmental effects were considered random.

An orthogonal Legendre polynomial of the cubic order was considered the most suitable for modeling the mean curve for the studied population. The general model can be represented by:

$$
Y i j=E F+\sum_{m=1}^{4} \beta m \emptyset m+\sum_{m=1}^{K a-1} \alpha i m \emptyset m+\sum_{m=1}^{k m-1} \gamma i m \emptyset m+\sum_{m=1}^{k c-1} \delta i m \emptyset m+\sum_{m=1}^{k q-1} \lambda i m \emptyset m+\varepsilon i j
$$

Wherein: is the weight in $j^{\text {ith }}$ day of the $i^{\text {th }}$ animal; $E F$ refers to a set of fixed effects of age-matched group (1.819 subclasses) and their covariant heifer age at calving (linear and quadratic effects); is a fixed regression coefficient of weight on Legendre polynomial, represented by a cubic function, and used to model the average growth curve of the population; is the polynomial function of Legendre of a standardized age $(-1<$ age $<1)$; are the regression coefficients of direct genetic, maternal genetic, animal permanent environmental, and maternal permanent environmental effects for each animal, respectively; , , are the order of polynomial to be fitted to each random effect; = random error associated with each age $i$ of the animal $j$.

The same model, with its respective assumptions, can be written in a matrix form as follows:

$$
v=\left[\begin{array}{l}
\mathbf{Y}=\mathbf{X} \boldsymbol{\beta}+\mathbf{Z}_{1} \boldsymbol{\alpha}+\mathbf{Z}_{2} \boldsymbol{\gamma}+\mathbf{W}_{\mathbf{1}} \boldsymbol{\delta}+\mathbf{W}_{\mathbf{2}} \boldsymbol{\lambda}+\boldsymbol{\varepsilon}, \text { being } \\
\gamma \\
\delta \\
\lambda \\
\varepsilon
\end{array}\right]=\left[\begin{array}{ccccc}
K_{a} \otimes A & 0 & 0 & 0 & 0 \\
0 & K_{m} \otimes A & 0 & 0 & 0 \\
0 & 0 & K_{c} \otimes I & 0 & 0 \\
0 & 0 & 0 & K_{q} \otimes I & 0 \\
0 & 0 & 0 & 0 & R
\end{array}\right]
$$


Wherein: $\mathrm{Y}$ is the vector of $\mathrm{N}$ observations regarding $N d$ animals; $\beta$ is a vector which contains the fixed effects and the regression coefficients $\boldsymbol{b}_{\boldsymbol{m}}$ of fixed effects; $\alpha$ is a vector $K a \times N_{D}$ of random regression coefficients of direct additive effects, wherein $N_{D}>N d$ denotes the total number of animals analyzed, i.e. in the kinship matrix $(5,678) ; \gamma$ is a vector $\mathrm{K}_{\mathrm{m}} \times \mathrm{N}_{\mathrm{D}}$ of random regression coefficients of maternal genetic effects; $\delta$ is a vector $\mathrm{K}_{\mathrm{c}} \times \mathrm{N}_{\mathrm{d}}$ of random regression coefficients of animal permanent environmental effect; $\lambda$ is a vector $\mathrm{K}_{\mathrm{q}} \mathrm{x}$ $\mathrm{N}_{\mathrm{m}}$ of random regression coefficients of maternal permanent environmental effects, being $\mathrm{N}_{\mathrm{m}}$ equal to the number of females with progenies included in the dataset; $\varepsilon$ is a vector of random errors; X, $\mathrm{Z}_{1}, \mathrm{Z}_{2}, \mathrm{~W}_{1}$, and $\mathrm{W}_{2}$ are the incidence matrices of fixed effects, direct genetic, maternal genetic, animal permanent environmental, and maternal permanent environmental effects, respectively; $K a, K c, K m$, and $K q$ are the (co) variance matrices among the regression coefficients of direct genetic, animal permanent environmental, maternal genetic, and maternal permanent environmental effects, respectively; $\boldsymbol{A}$ is the numerator matrix of the coefficients of relationship among individuals; Ind $_{\boldsymbol{N d}}$ is an identity matrix of size $\mathrm{Nd} ; \mathbf{I}_{\mathrm{Nm}}$ is an identity matrix of size Nm; $\otimes$ is the Kronecker product; and
$\mathrm{R}$ is a diagonal matrix of residual variances, whose size varies with the analysis structure.

The covariance between direct genetic and maternal effects was assumed to be zero. The (co) variances among the random regression coefficients of direct and maternal genetic effects and animal and maternal permanent environmental effects, according to the fitted model were estimated by restricted maximum likelihood method (REML), using the software WOMBAT (MEYER, 2006).

The random effects were fitted with thirdorder Legendre polynomials, and the order of each effect increased gradually until the best fitting was achieved. The different models were compared by the logarithm of the likelihood function ( $\log$ L), Akaike information criterion (AIC) and the Bayesian information criterion of Schwarz (BIC).

\section{Results and Discussion}

Means and standard deviations of weights increased linearly from birth to the age of 660 days (Table 2), with means ranging from $30.7 \pm 4.1$ to $347.5 \pm 121.7 \mathrm{~kg}$, respectively. Such results are similar to those described by Ferreira et al. (2015) for animals of the Nellore breed.

Table 2. Descriptive analysis of weight-for-age data from Polled Nellore cattle reared in northern Brazil.

\begin{tabular}{ccccccc}
\hline Age (days) & N & Average $(\mathrm{Kg})$ & SD & CV $(\%)$ & Minimum $(\mathrm{Kg})$ & Maximum $(\mathrm{kg})$ \\
\hline 1 & 93 & 30.7 & 4.1 & 13.3 & 28 & 56 \\
120 & 77 & 124.1 & 20.6 & 16.6 & 89 & 172 \\
240 & 116 & 189.4 & 37.2 & 19.6 & 111 & 370 \\
365 & 77 & 242.7 & 50.3 & 20.7 & 155 & 415 \\
550 & 68 & 290.6 & 85.0 & 29.3 & 180 & 674 \\
660 & 8 & 347.5 & 121.7 & 35.0 & 182 & 520 \\
\hline
\end{tabular}

N: Frequency; SD: standard deviation; CV: coefficient of variation.

The use of random regression models by Legendre polynomial functions lacked a basic order (quadratic) for each random effect considered. Later, the fitting orders for continuous functions were gradually increased; so that a minimum order needed to describe (co) variance structures over time could be found for each random effect. 
Table 3 displays the summary of analyses using the random regression models, with the values of $\log \mathrm{L}, \mathrm{AIC}$, and BIC presented as a deviation in relation to the lowest value.

The fitting orders of continuous functions were defined sequentially, starting with genetic direct and maternal effects, and hence the environmental ones. The fitting order increased by observing the criteria values until obtaining an order that best fit each effect.
Other authors, such as Lôbo et al. (2010) and Albuquerque and Faro (2008), have already studied the modeling of beef-cattle growth curve using the Legendre orthogonal polynomials. They found that parsimonious models are preferable. In other words, models involving a minimum number of parameters to be estimated and that well explain the response variable behavior should be given preference. According to Meyer (2005), another positive aspect would be a smaller demand for computational resources, and hence lower susceptibility to numerical errors.

Table 3. Logarithm of maximum likelihood function $\log (\mathrm{L})$, Akaike information criterion (AIC), Bayesian information criterion (BIC), number of estimated parameters (NP), expressed as the absolute deviation of the lowest value.

\begin{tabular}{|c|c|c|c|c|}
\hline Model $^{1}$ & NP & $\log L^{2}$ & $\mathrm{AIC}^{2}$ & $\mathrm{BIC}^{2}$ \\
\hline 1- 2222 & 19 & 739.0 & 1422.3 & 1219.8 \\
\hline $2-\quad 3333$ & 31 & 332.6 & 633.3 & 520.9 \\
\hline 3- 5333 & 40 & 47.3 & 80.8 & 35.8 \\
\hline 4- 5433 & 44 & 46.2 & 86.5 & 71.5 \\
\hline 5- 5533 & 49 & 45.3 & 94.8 & 117.3 \\
\hline $6-5343$ & 44 & 38.9 & 72.0 & 57.0 \\
\hline 7- 5543 & 53 & 34.9 & 81.9 & 134.4 \\
\hline 8- 6333 & 46 & 0.9 & 0.0 & 0.0 \\
\hline 9- 6433 & 50 & 0.0 & 6.2 & 36.2 \\
\hline
\end{tabular}

${ }^{1}$ Fitting order for additive genetic effects (direct and maternal) and permanent environmental effects (maternal and animal), respectively

${ }^{2}$ Values expressed as the deviation of the lowest value.

As for the criterion of Log L, the highest orders for random effects produced better values; however, the excessive increase in the fitting orders of effects contributed to an increased parameterization of the model. Model 9 (6433), with 50 parameters, provided a better fit according to the Log L, but it should not be the only criterion to be used.

The values of Akaike information criterion (AIC) improved with the increase of fitting orders up to a certain point. According to this criterion, the model considering functions with the orders 6333 (46 parameters) was superior to the other models in the fitting of (co) variance along the growth track.
Corroborating with the above statement, the Bayesian information criterion (BIC), which imposes more stringent penalties than the AIC given the number of estimated parameters, is in accordance with the indication of model 8 (6333) for the fitting of (co) variances along the growth track.

Thus, model 8 showed the lowest values of AIC and BIC. These results indicate that, although this model did not have the best value of Log L, it is efficient to explain the data variation properly, without turning into an excessive number of parameters. 
When fitting fewer parameterized models with the highest order being three, Fischer et al. (2004) found the best fit for those with orders equal to 3233 , for genetic direct and maternal effects and maternal and animal permanent environmental effects for the animal and its mother, respectively.

In general, the highest values of variance were obtained at the point of interception of all effects (Table 4). The correlation between this point and a quadratic coefficient were negative for all random effects. Moreover, a positive correlation was observed between the intercept and linear coefficient for all random effects. The intercept explained the largest proportion of variance in all random effects included in the model and explained the maternal permanent environmental effect almost entirely (99\%).

In highly parameterized models, eigenvalues are often close to zero, which might have been caused by the increased multicollinearity by raising the order of fit of the function used (SARMENTO et al., 2006).

Estimates of the variances of genetic additive direct, animal permanent environmental and phenotypic effects tended to grow as the age of the animals increased (Figure 2).

Table 4. Estimates of variance (diagonal), covariance (below the diagonal), and correlation (above the diagonal) between random regression coefficients and eigenvalues associated with the matrix of coefficients for the model with $\mathrm{k}=6333$.

\begin{tabular}{|c|c|c|c|c|c|c|c|}
\hline & 0 & 1 & 2 & 3 & 4 & 5 & Eigenvalue \\
\hline & \multicolumn{6}{|c|}{ Additive genetic effect $\left(\mathrm{k}_{\mathrm{a}}=6\right)$} & $(\%)$ \\
\hline 0 & 228.88 & 0.72 & -0.42 & 0.15 & 0.34 & -0.10 & 73.09 \\
\hline 1 & 97.47 & 80.69 & -0.24 & -0.57 & 0.27 & -0.01 & 13.24 \\
\hline 2 & -26.31 & -9.20 & 17.50 & 0.05 & -0.84 & 0.15 & 7.16 \\
\hline 3 & 9.80 & -22.18 & 0.87 & 19.07 & -0.10 & -0.04 & 5.87 \\
\hline 4 & 21.99 & 10.46 & -15.02 & -1.87 & 18.07 & 0.05 & 0.64 \\
\hline \multirow[t]{2}{*}{5} & -7.04 & -0.61 & 2.93 & -0.88 & 1.11 & 22.77 & 0.00 \\
\hline & \multicolumn{7}{|c|}{ Maternal additive genetic effect $\left(\mathrm{k}_{\mathrm{a}}=3\right)$} \\
\hline 0 & 35.48 & 0.70 & -0.44 & & & & 91.13 \\
\hline 1 & 6.76 & 2.61 & 0.33 & & & & 8.86 \\
\hline \multirow[t]{2}{*}{2} & -4.47 & 0.90 & 2.87 & & & & 0.00 \\
\hline & \multicolumn{7}{|c|}{ Animal permanent environmental effect $(\mathrm{kc}=3)$} \\
\hline 0 & 367.24 & 0.88 & -0.31 & & & & 92.58 \\
\hline 1 & 172.48 & 103.57 & 0.17 & & & & 7.42 \\
\hline \multirow[t]{2}{*}{2} & -26.01 & 7.43 & 18.94 & & & & 0.00 \\
\hline & \multicolumn{7}{|c|}{ Maternal permanent environmental effect $(\mathrm{kc}=3)$} \\
\hline 0 & 130.62 & 0.99 & -0.99 & & & & 99.99 \\
\hline 1 & 29.74 & 6.77 & -0.99 & & & & 0.01 \\
\hline 2 & -37.42 & -8.52 & 10.72 & & & & 0.00 \\
\hline
\end{tabular}


Figure 2. Estimates of variance values for additive genetic direct $\left(\mathrm{S}^{2} \mathrm{a}\right)$ and maternal $\left(\mathrm{S}^{2} \mathrm{~m}\right)$ effects, animal $\left(\mathrm{S}^{2} \mathrm{pe}\right)$ and maternal permanent environmental ( $\left.\mathrm{S}^{2} \mathrm{mpe}\right)$ effects, half of the phenotypic variance ( $\left.\mathrm{S}^{2} \mathrm{f}\right)$, and residual variance (S2e).
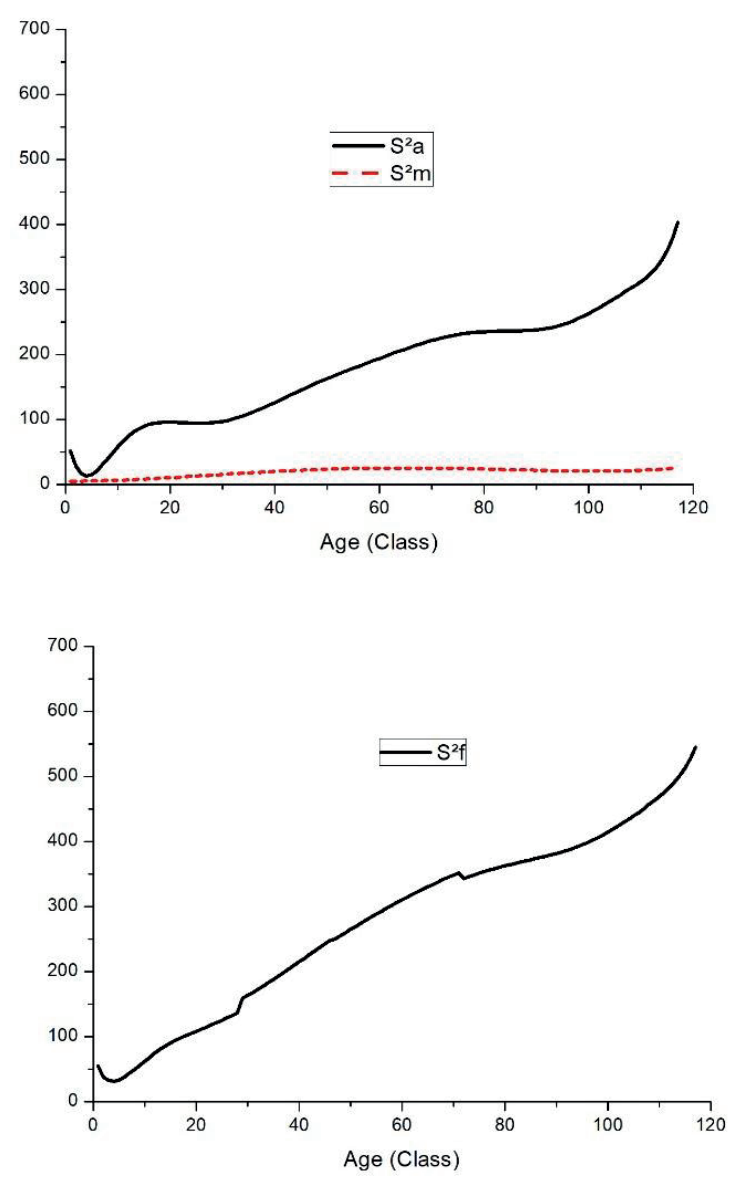

The highest values of variance of permanent environmental effect reflected directly upon phenotypic variance, especially at the end of the curve. Albuquerque and Meyer (2001) and Boligon et al. (2010) reported the similar behavior of permanent environmental effect by assessing the growth track of Nellore cattle.

In this study, the direct maternal effect had less influence on the total phenotypic variance, which presented slight growth at the beginning of the track but remained almost constant after 300 days. The maternal permanent environmental effect has grown markedly from birth to near 400 days of age. Generally, most studies that include maternal effects in growth analyses have shown reductions after weaning, thus indicating their low importance
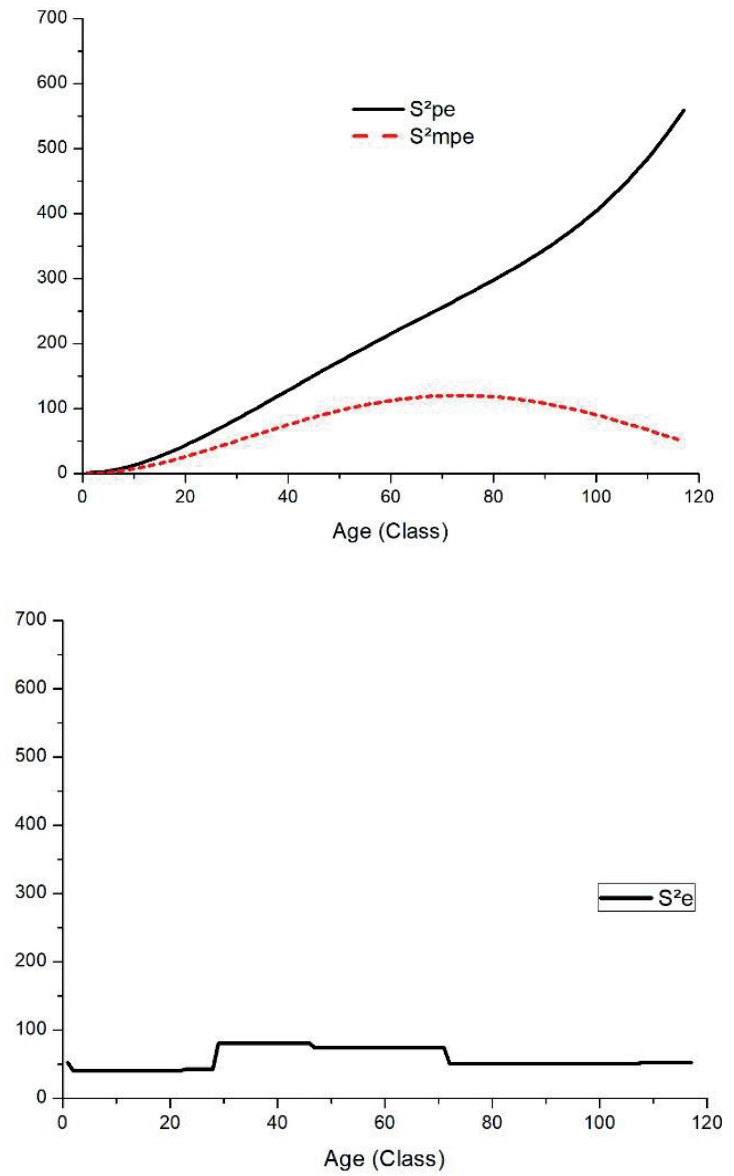

at more advanced ages (BOLIGON et al., 2012). However, the inclusion of maternal effects for data analysis in this study contributed to a better division of variance in and between cows, as well as to break down total variance. On the one hand, such inclusion generates genetic value estimates that are more accurate; on the other hand, non-inclusion could overestimate genetic direct additive variance and hence animal genetic values, which would result in a lower genetic gain than expected.

Direct heritability estimates showed a significant drop at the beginning of the curve, resuming growth soon after. This oscillation of growth remains until day 180 , with mean values between 0.30 and 0.40 , and returning to grow at the end of the interval up to 0.42 (Figure 3). For weights near birth, 
overestimated heritabilities were found, just as the findings of Passafaro et al. (2016) (above 0.60). These results were different from what was reported by Sousa Júnior et al. (2010), who observed an increase in direct heritability from near zero to stabilize at around 0.30 , from 145 days of age on.

Figure 3. Estimates of direct $\left(\mathrm{h}^{2}\right)$ and maternal $\left(\mathrm{m}^{2}\right)$ heritabilities, and variance components for animal permanent environmental $\left(\mathrm{c}^{2}\right)$ and maternal $\left(\mathrm{q}^{2}\right)$ effects, as a proportion of the phenotypic variance for 117 age classes, using random regression model.

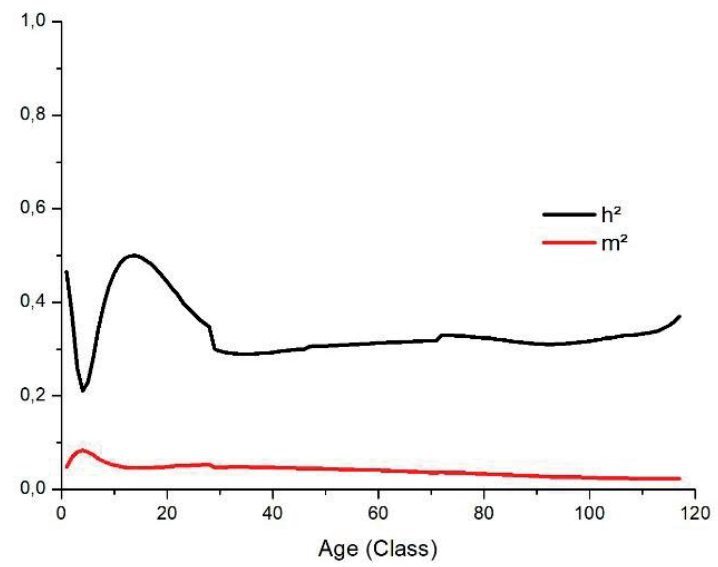

The overestimation of direct heritability at the beginning of the curve is due to the higher values of direct variances, as shown in Figure 2. At the beginning and at the end of the interval of ages, heritability values should be evaluated carefully. This is because the curve fit for additive genetic direct effect might not have been appropriate, what occurs due to a scant amount of data collected (PASSAFARO et al., 2016).

In this study, direct heritability means were lower than the minimum of 0.58 estimated by Scalez et al. (2014) for the post-weaning weight of Nellore cattle in a weight gain test. Such discrepancy between both studies may be due to non-inclusion of maternal effects by Scalez et al. (2014), which might have overestimated the direct additive variance.

The variance of permanent environmental direct effect expressed as a proportion of the phenotypic variance, had a strong growth over the entire range (Figure 3). In general, the magnitude of this component was medium to high, with a minimum value of 0.004 and a maximum of 0.56 . This trend

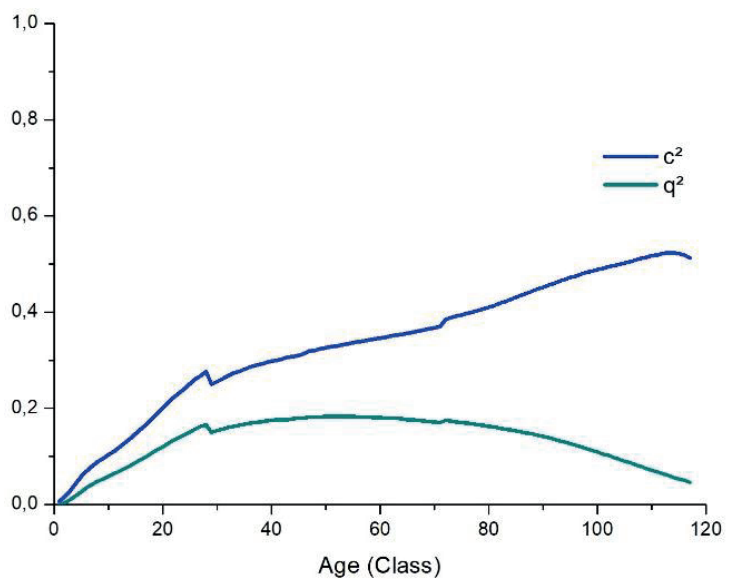

can be justified due to the cumulative nature of this effect (SCHAEFFER; JAMROZIK, 2008). This inconstant behavior of permanent environmental effect was also observed by Albuquerque and Meyer (2001) and by Nephawe (2004).

Maternal heritability values had a low to medium magnitude, with a minimum value of 0.02 and a maximum of 0.07 . In general, the maternal heritability values suggest that selection for this component will be less responsive than that for direct heritability. Albuquerque and Meyer (2001), Nobre et al. (2003) and Boligon et al. (2010) obtained different trends for this effect, increasing from birth to 205 days and reducing after weaning.

The variance means for maternal permanent environmental effect, expressed as a proportion of phenotypic variance, tend to increase from birth to 300 days, gradually decreasing from this point until the end of the interval (Figure 3)

In general, the maternal effects in this study showed a reduction after weaning, indicating their slight contribution at more advanced ages. 


\section{Conclusions}

A Legendre polynomial function with the orders six, three, three, and three for genetic additive direct and maternal effects, animal and maternal permanent environmental effects, respectively, can be used to describe changes in (co) variance throughout the growth curve of Polled Nellore cattle in northern Brazil.

\section{References}

ALBUQUERQUE, L. G.; FARO, L. E. Comparação entre os valores genéticos para características de crescimento de bovinos da raça Nelore preditos com modelos de dimensão finita e infinita. Revista Brasileira de Zootecnia, Viçosa, MG, v. 37, n. 2, p. 238-246, 2008.

ALBUQUERQUE, L. G.; MEYER, K. Estimates of covariance functions for growth from birth to 630 days of age in Nelore cattle. Journal of Animal Science, Champaign, v. 79, n. 11, p. 2776-2789, 2001.

ASSOCIAÇÃO BRASILEIRA DOS CRIADORES DE ZEBU - ABCZ. Estatísticas. Uberaba: Bela Vista Cultural, 2012. Disponível em: <www.abcz.org.br/ conteudo/tecnica/estatisticas.html>. Acesso em: $15 \mathrm{fev}$. 2012.

BOLIGON, A. A.; ALBUQUERQUE, L. G.; MERCADANTE, M. E. Z.; LÔBO, R. B. Study of relations among age at first calving, average weight gains, and weights from weaning to maturity in Nellore cattle. Revista Brasileira de Zootecnia, Viçosa, MG, v. 39, n. 4, p. 746-751, 2010.

BOLIGON, A. A.; MERCADANTE, M. E. Z.; LOBO, R. B.; BALDI, F.; ALBUQUERQUE, L. G. Random regression analyses using B-spline functions to model growth of Nellore cattle. Animal, Cambridge, v. 6, n. 2, p. 212-220, 2012.

FERREIRA, J. L.; LOPES, F. B.; PEREIRA, L. S.; NEPOMUCENO, L. L.; GARCIA, J. A. S.; LÔBO, R. B.; SAINZ, R. D. Estimação de componentes de (co) variâncias para características de crescimento em bovinos Nelore criados no Trópico Úmido do Brasil por meio de regressão aleatória. Semina: Ciências Agrárias, Londrina, v. 36, n. 3, p. 1713-1724.

FISCHER, T. M.; VAN DER WERF, J. H. J.; BANKS, R. G.; BALL, A. J. Description of lamb growth using random regression on field data. Livestock Production Science, Amsterdam, v. 89, n. 2-3, p. 175-185, 2004.
GONÇALVES, F. M.; PIRES, A. V.; PEREIRA, I. G.; GARCIA, D. A.; FARAH, M. M.; MEIRA, C. T.; CRUZ, V. A. R. Avaliação genética para peso corporal em um rebanho Nelore. Arquivo Brasileiro de Medicina Veterinária e Zootecnia, Belo Horizonte, v. 63, n. 1, p. 158-164, 2011.

JAMROZIK, J.; SCHAEFFER, L. R. Estimates of genetic parameters for a test day model with random regression for yield traits of first lactation Holsteins. Journal of Dairy Science, Champaign, v. 80, n. 4, p. 762-770, 1997.

KIRKPATRICK, M.; HECKMAN, N. A quantitative genetic model for growth, shape, reaction norms, and other infinite-dimensional characters. Journal of Mathematical Biology, Heidelbergv, v. 27, n. 4, p. 429450, 1989.

LAUREANO, M. M. M.; BOLIGON, A. A.; COSTA, R. B.; FORNI, S.; SEVERO, J. L. P.; ALBUQUERQUE, L. G. Estimativas de herdabilidade e tendências genéticas para características de crescimento e reprodutivas em bovinos da raça Nelore. Arquivo Brasileiro de Medicina Veterinária e Zootecnia, Belo Horizonte, v. 63, n. 1, p. 143-152, 2011.

LÔBO, R. N. B.; BITTNECOURT, T. C. B. S. C.; PINTO, L. F. B. Progresso científico em melhoramento animal no Brasil na primeira década do século XXI. Revista Brasileira de Zootecnia, Viçosa, MG, v. 39, n. 1, p. 223-235, 2010.

MALHADO, C.H.M.; CARNEIRO, P.L.S.; PEREIRA, D.G.; MARTINS FILHO, R. Progresso genético e estrutura populacional do rebanho Nelore no Estado da Bahia. Pesquisa Agropecuária Brasileira, Cruz das Almas, v. 43, n. 9, p. 1163-1169, 2008.

MEYER, K. Estimates of covariance functions for growth of Angus cattle from random regression analyses fitting B-spline functions. Proceedings of the Association for Advancement of Animal Breeding Genetics, Armidale, v. 16 , n. 1, p. 52-55, 2005.

MEYER, K. WOMBAT - A program for mixed model analyses by restricted maximum likelihood. Journal of Zhejiang University Science B, Zhejiang, v. 8, n. 11, p. 815-821, 2007.

MEYER, K. WOMBAT - Digging deep for quantitative genetic analyses by restricted maximum likelihood. In: WORLD CONGRESS ON GENETIC APPLIED TO LIVESTOCK PRODUCTION, 8., 2006, Belo Horizonte. Proceedings... Belo Horizonte: Instituto Prociência, 2006. CD-ROM.

MEYER, K.; HILL, W. G. Estimation of genetic and phenotypic covariance functions for longitudinal 
repeated records by restricted maximum likelihood. Livestock Production Science, Amsterdam, v. 47, n. 3, p. 85-200, 1997.

NEPHAWE, K. A. Application of random regression models to the genetic evaluation of cow weight in Bonsmara cattle of South Africa. South African Journal Animal Science, Alice, v. 34, n. 3, p. 166-173, 2004.

NOBRE, P. R. C.; MISZTAL, I.; TSURUTA, S.; BERTRAND, J. K. L.; SILVA, O. C.; LOPES, P. S. Analyses of growth curves of Nelore cattle by multipletrait and random regression models. Journal Animal Science, Champaign, v. 81, n. 4, p. 918-926, 2003.

PASSAFARO, T. L.; FRAGOMENI, B. D. O.; GONÇALVES, D. R.; MORAES, M. M. D.; TORAL, F. L. B. Genetic analysis of body weight in a Nellore cattle herd. Pesquisa Agropecuária Brasileira, Brasília, v. 51, n. 2, p. $149-158,2016$.

SARMENTO, J. L. R.; TORRES, R. A.; PEREIRA, C. S.; EUCLYDES, R. F. Avaliação genética de características de crescimento de ovinos Santa Inês utilizando modelos de regressão aleatória. Arquivo Brasileiro de Medicina Veterinária e Zootecnia, Belo Horizonte, v. 58, n. 1, p. 68-77, 2006.

SCALEZ, D. C. B.; FRAGOMENI, B. O.; PASSAFARO, T. L.; PEREIRA, I. G.; TORAL, F. L. B. Polynomials to model the growth of young bulls in performance tests. Animal, Cambridge, v. 8, n. 3, p. 370-378, 2014.

SCHAEFFER, L. R.; JAMROZIK, J. Random regression models: a longitudinal perspective. Journal of Animal Breeding and Genetics, Hoboken, v. 125, n. 3, p. 145146, 2008.

SOUSA JÚNIOR, S. C.; OLIVEIRA, S. M. P.; ALBUQUERQUE, L. G.; BOLIGON, A. A.; MARTINS FILHO, R. Estimação de funções de covariância para características de crescimento da raça Tabapuã utilizando modelos de regressão aleatória. Revista Brasileira de Zootecnia, Viçosa, MG, v. 39, n. 5, p. 1037-1045, 2010. 
